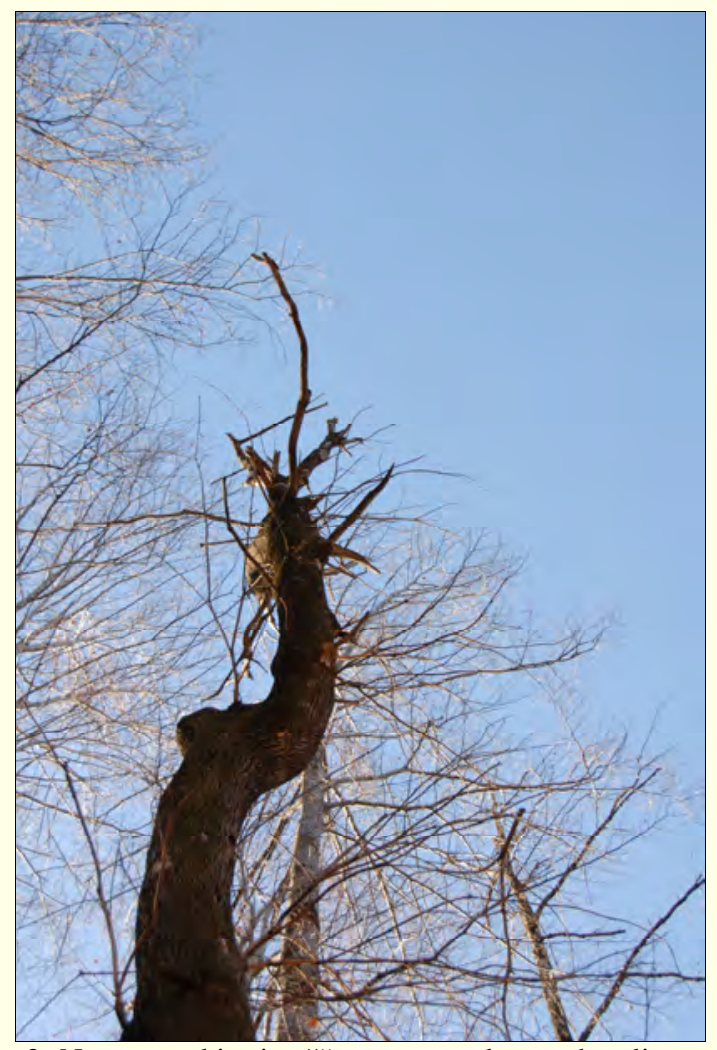

Slika 3: Na mestu, kjer izrašča grm navadnega ohmelja, se veja pogosto odlomi. Posledice so za drevo lahko tako drastične, da lahko ostane skoraj brez vej.

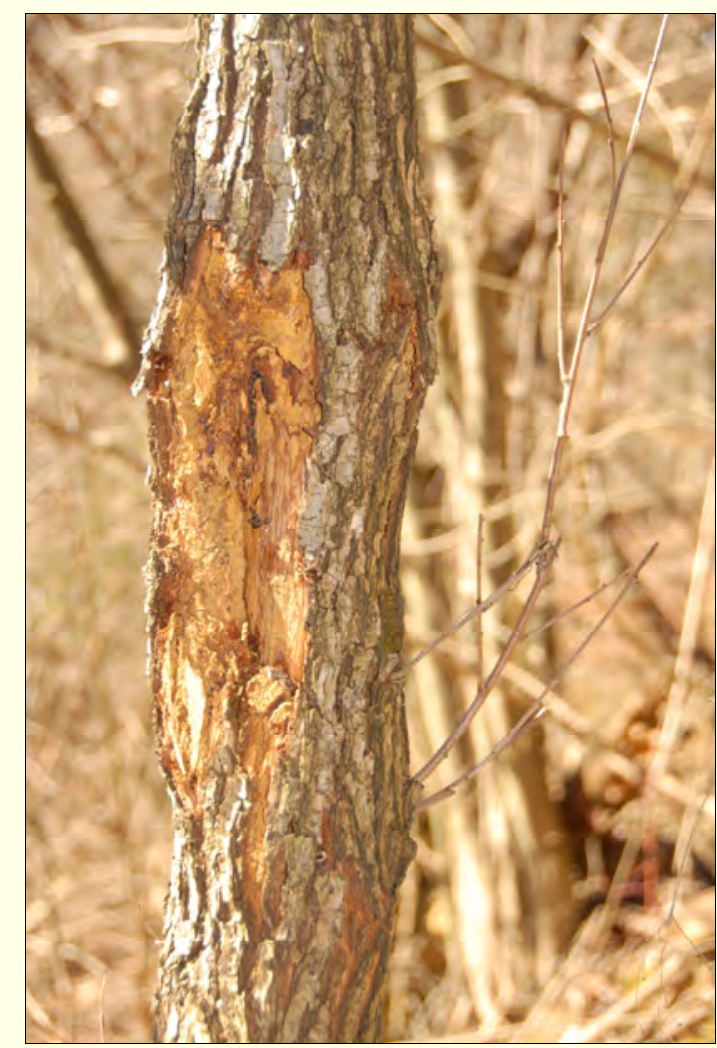

Slika 4: Graden je okužila gliva Chryphonectria parasitica, ki povzroča kostanjev rak.

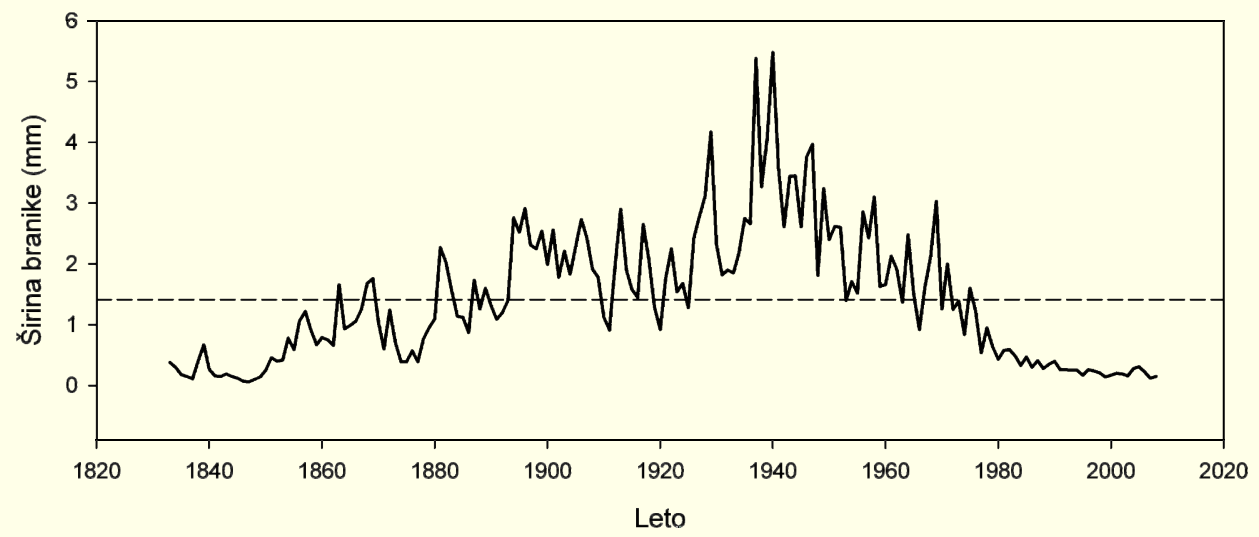

Slika 5: Širina branik za celotno življenjsko obdobje posekanega gradna na Dularjevem hribu (1832-2008).

\title{
Rdeči bor se je začel sušiti po toči
}

\section{Marija KOLŠEK ${ }^{1 *}$, Franc KOGOVŠEK ${ }^{2}$, Dušan JURC ${ }^{3}$}

Ob dolenjski avtocesti v smeri Ljubljana - Novo mesto severovzhodno od Grosuplja je dne 17. 6. 2010 kot oreh debela toča povzročila poškodbe na približno 60 ha gozda. Na neurje so najprej opominjale le razcefrane listne površine zelišč, grmovja in dreves. Ob koncu junija so na najbolj prizadetem območju začele rjaveti krošnje borov. Sušenje rdečega bora (Pinus sylvestris L.) je zaradi opazne lege ob avtocesti povzročilo veliko zanimanje oziroma zaskrbljenost javnosti.

Sušenje borov je povzročila zajedalska gliva, ki je okužila rane na skorji. Bori imajo v primerjavi z drugimi drevesnimi vrstami izredno veliko število splošno razširjenih in nevarnih glivičnih bolezni. Z izolacijo gliv v čisto kulturo smo ugotovili, da v ranah zaradi 
toče prevladuje gliva Diplodia pinea (Desm.) J. Kickx f. (sin. Sphaeropsis sapinea (Fr.) Dyko \& B. Sutton), povzročiteljica bolezni borov z imenom sušica najmlajših borovih poganjkov. Gliva povzroča odmiranje skorje, ki se širi okoli rane in povzroči odmiranje vej; gliva se lahko tudi razraste $\mathrm{v}$ deblo in povzroči odmiranje celega drevesa in modrenje lesa (Jurc, 2007). Bolezen je splošno razširjena $\mathrm{v}$ okolici Ljubljane, povzroča odmiranje mladih poganjkov in vej predvsem črnega bora, ob močnem sušnem stresu pa tudi odmiranje dreves. Na Golovcu pri Ljubljani so se leta 2001 sušila odrasla drevesa rdečega bora (Jurc D. in Jurc M., 2002). Zajedavska gliva Diplodia pinea je splošno razširjena tudi po vsej Sloveniji, okuži in uniči predvsem zaradi suše oslabele bore in v zadnjih letih povzroča zlasti obsežno sušenje krošenj črnih borov na Krasu.

Lastnikom gozdov na poškodovanem območju smo svetovali posek borov s poškodovanostjo krošnje več kot 80 \%, ker bodo zaradi okužbe z glivo odmrla. Ker obstaja verjetnost, da se na poškodovanih borih in dru- gih iglavcih namnožijo podlubniki, je potrebno redno spremljanje stanja poškodovanega gozda. Na obravnavanem območju so bile že poleti 2010 evidentirane posamezne s podlubniki napadene smreke.

\section{Viri}

Jurc D., Jurc M. 2001. Rdeči bor (Pinus sylvestris) se na Golovcu suši zaradi sušice najmlajših borovih poganjkov (Sphaeropsis sapinea). Gozdarski inštitut Slovenije in Gozdarski oddelek BF, Poročevalska, diagnostična in prognostična služba za varstvo gozdov, 3 str.

Jurc D. 2007. Bori - Pinus spp.: bolezni poganjkov, vej in debla: Sphaeropsis sapinea, Cenangium ferruginosum, Sydowia polyspora. Gozdarski vestnik, Ljubljana, 65, 1: [129-144], 25-40

1Zavod za gozdove Slovenije, Večna pot 2, 1000 Ljubljana; 'Zavod za gozdove Slovenije, Krajevna enota Grosuplje, Taborska n.n., 1290 Grosuplje; ${ }^{3}$ Gozdarski inštitut Slovenije, Večna pot 2, 1000 Ljubljana *marija.kolsek@zgs.gov.si

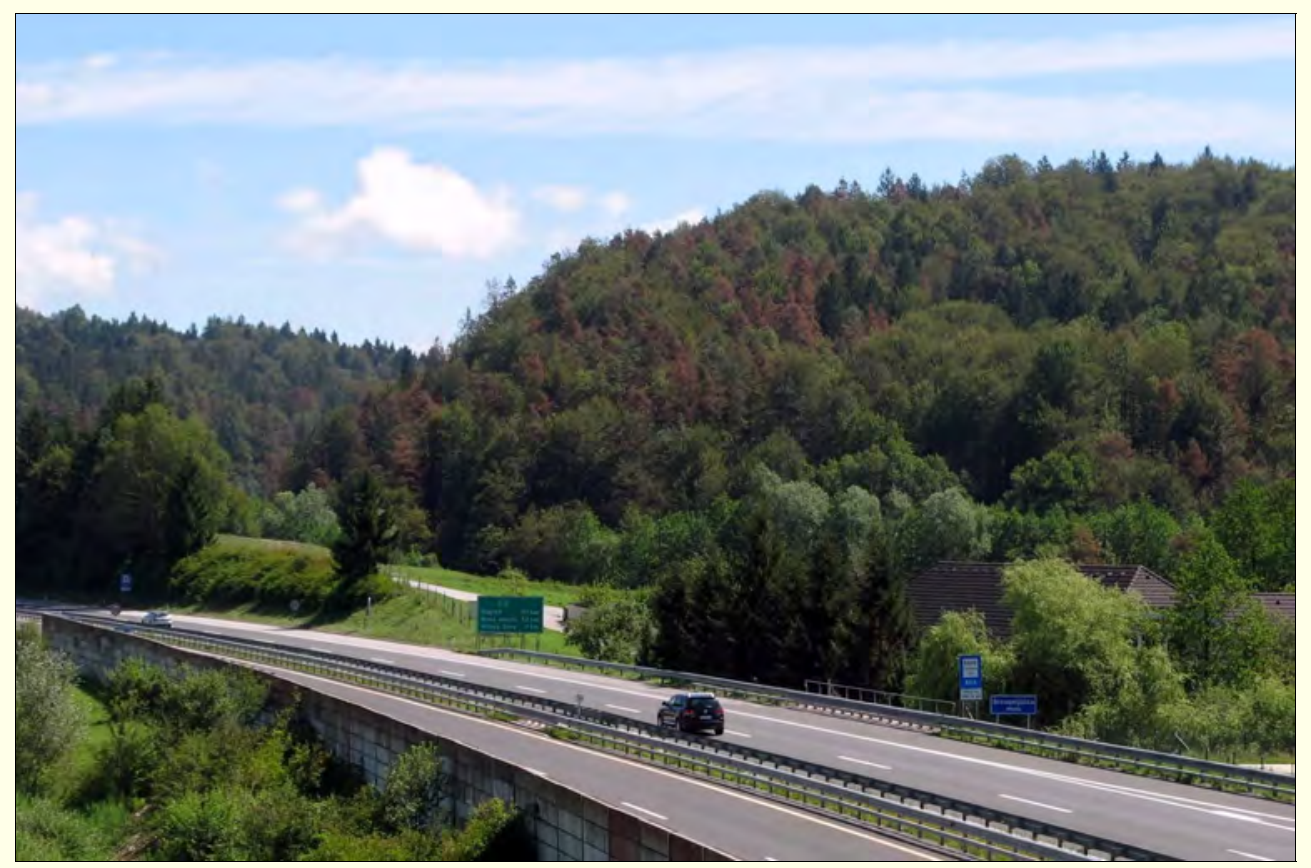

Slika 1: Sušenje borov ob avtocesti pri Grosuplju je posledica toče in naknadnih okužb z glivami (foto: Barbara Piškur, Gozdarski inštitut Slovenije)

\section{Ukrepi proti namnožitvi zapredkaric (Cephalcia spp.) na Riflovem vrhu pri Prevaljah v letu 2010}

\section{Gorazd MLINŠEK ${ }^{1 *}$, Janko MIKELN ${ }^{2}$, Franjo ŠTERN $^{2}$, Marija KOLŠEK $^{3}$}

V letu 2009 so bile v Sloveniji prvič evidentirane poškodbe sestojev, ki so jih povzročile rastlinske ose zapredkarice iz rodu Cephalcia (Hymenoptera: Pamphiliidae). Predstavniki rodu Cephalcia, ki se avtohtono pojavljajo v Evropi, lahko ob večletnih namnožitvah povzročijo poškodbe na velikih površinah - defoliacije in posledično zaradi sečnje oslabelih dreves tudi večje ogolele površine. Poškodbe povzročajo ličinke z obje- danjem iglic zlasti na smreki in redkeje na drugih iglavcih. Prvo obvestilo o namnožitvi zapredkaric pri nas je v prispevku M. Jurc, G. Mlinšek: Zapredkarice (Cephalcia spp.) na vejah navadne smreke na Koroškem pri Prevaljah. Novice iz varstva gozdov št. 2, 2009, stran 12-13. V tem prispevku poročamo o ugotavljanju obsega poškodovanosti in o ukrepanju Zavoda za gozdove Slovenije. 